\title{
Lithraea australis (Berry) comb. nov. (Anacardiaceae) from the upper section of Ñirihuau Formation (middle Miocene), Patagonia
}

\author{
Mauro G. Passalia a,b,e,*, Nicolás Caviglia ${ }^{\text {c,e }}$, Ezequiel I. Vera ${ }^{\text {c,d,e }}$ \\ a Instituto de Investigaciones en Biodiversidad y Medioambiente (INIBIOMA, CONICET-UNCo), Av. de los Pioneros 2350 (8400), S.C. de Bariloche, Río Negro, Argentina \\ b Sede Alto Valle y Valle Medio, Universidad Nacional de Río Negro, Isidro Lobo 516, Gral. Roca, Río Negro, Argentina \\ ' Museo Argentino de Ciencias Naturales "Bernardino Rivadavia”, CONICET. Av. Ángel Gallardo 470 (C1405DJR), Buenos Aires, Argentina \\ d Área de Paleontología, Departamento de Geología, Universidad de Buenos Aires, Pabellón 2, Ciudad Universitaria (C1428EGA), Buenos Aires, Argentina \\ e Consejo Nacional de Investigaciones Científicas y Técnicas (CONICET), Argentina
}

\section{A R T I C L E I N F O}

\section{Article history:}

Received 18 October 2018

Received in revised form 11 March 2019

Accepted 1 April 2019

Available online 04 April 2019

\section{Keywords:}

Lithraea

Transitional Province

Zamia australis

Paleobotany

Neogene

\begin{abstract}
A B S T R A C T
The first records of fossil plants from the Nirihuau Formation (middle Miocene) were published by Edward Berry at the beginning of the last century. They consist of a small collection of leaf imprints obtained from the southern margin of the Ñirihuau River valley, western Río Negro, Argentina. Based on these records, Berry described a few ferns, gymnosperms and angiosperms. Among these impressions, stand out two specimens that Berry interpreted as pinnate leaves of Cycadaceae (now Zamiaceae) that he assigned to the new species Zamia australis Berry. However, after a review of Berry's original materials of $Z$. australis, and new specimens collected in recent years in the same fossil locality, it is concluded that these putative zamiaceous remains are in fact angiosperm leaves. They show great similarity with those of the current South American species Lithraea molleoides (Vell.) Engl. (Anacardiaceae). To encompass these remains, a new combination, Lithraea australis (Berry) is proposed. From a paleophytogeographic point of view, the recognition of a L. molleoides closely related species suggests that the plant communities of the upper section of the Ñirihuau Formation were part of the "Transitional Province" or at least constituted the ecotone between it and the "Nothofagidites" Province.
\end{abstract}

(c) 2019 Published by Elsevier B.V.

\section{Introduction}

The family Anacardiaceae R. Brown. nom.cons. includes about 70 genera and 600 species of trees (mainly), shrubs and lianas mostly of pantropical distribution, but also including temperate species (Pell et al., 2011). They grow in a variety of environments, from climax communities in tropical evergreen and deciduous forests, disturbed environments, mangrove coastal areas, as well as under xerophilous conditions (Martínez-Millán and Cevallos-Ferriz, 2005).

In southern South America (including Argentina, Chile, Uruguay, Paraguay and southern Brazil) the family is represented by 9 genera (Anacardium L., Astronium Jacq., Haplorhus Engl., Lithraea Miers ex Hook. et Arn., Loxopterygium Hook., Mauria Kunth, Schinopsis Engl.,

\footnotetext{
* Corresponding author at: Instituto de Investigaciones en Biodiversidad y Medioambiente (INIBIOMA, CONICET-UNCo), Av. de los Pioneros 2350 (8400), S.C. de Bariloche, Río Negro, Argentina.

E-mail addresses: passaliam@comahue-conicet.gob.ar (M.G. Passalia), evera@macn.gov.ar (E.I. Vera).
}

Schinus L., Tapirira Aubl.), and around 17 endemic species (Zuloaga et al., 2008).

The fossil history of the Anacardiaceae includes an extensive worldwide Paleo-Neogene record (e.g. Poole et al., 2001; Ramírez and Cevallos-Ferriz, 2002; Burnham and Carranco, 2004; Manchester et al., 2007; Pujana, 2009; Kvaček et al., 2015; Qiong-Yao et al., 2017; Fu et al., 2017). Possibly the oldest occurrences correspond to woods from the latest Cretaceous - earliest Paleocene of India, with diagnostic features of the subfamily Anacardioideae Takhtajan (Wheeler et al., 2017). Molecular phylogenies calibrated by fossils estimate the age of the crown-group of Anacardiaceae ranging from 54.8 to $97 \mathrm{Ma}$ (summarized in Stevens, 2001-onwards).

The fossil evidence of the family Anacardiaceae in Argentina includes woods, pollen and leaves beginning from the Danian and extending throughout the Cenozoic (summarized in Mautino and Anzótegui, 2014; but also Barreda et al., 2009; Pujana, 2009; Martinez and Pujana, 2010; Quattrocchio et al., 2012; Cornou et al., 2014; Césari et al., 2015).

In this contribution, a fossil leaf type is described and assigned to the Anacardiaceae, based on historical (Berry, 1928; Fiori, 1939) and new samples from the Miocene of the Ñrihuau Basin in northwestern 
Patagonia. The phytogeographic implications derived from this fossil record are briefly discussed.

\section{Material and methods}

\subsection{Provenance and repositories of fossil remains}

The fossils studied here consist mainly of impressions and compressions of isolated leaves or leaflets, without preserved cuticle or epidermal details. The specimens come from deposits located on the southern margin of the Nirihuau River valley (Estancia El Desafío), western Río Negro Province, Argentina (Fig. 1). There are previous and historical paleobotanical collections from this locality, while new samples have been carried out in recent years. This fossiliferous locality is mentioned in the literature as "locality 198" (Berry, 1928), "Medio río Ñirihuau" (Fiori, 1939) and "Ñirihuau Medio" (Romero and Dibbern, 1984) a name here followed, although is also known as "3 Alamos." The new specimens are housed at the Museo de Paleontología de Bariloche (MAPBAR), S.C. de Bariloche, Río Negro Province, and the Colección de Paleobotánica del Repositorio de Paleontología, Facultad de Ciencias Exactas y Naturales, Universidad de Buenos Aires (BAFC$\mathrm{Pb})$, Buenos Aires, Argentina.

The historical collection of Berry (1928) from Locality 198 was also considered in this study, based on high resolution images. These specimens were collected and sent to Edward Berry by Chester W. Washburne (circa 1926) and are housed at the National Museum of Natural History, Smithsonian Institution (USNM). The exact location of the site 198 is unknown. To this respect Berry (1928) states: Southeast side of Rio Nirihuao, 1 1⁄2 leagues above foot of canyon, 150 yards southwest of Casa Piedra (4 leagues south of Lago Nahuel Huapi). Few years later, Egidio Feruglio apparently rediscovered the same Locality 198 of Washburne on the ladera derecha del valle del Río Nirihuau, inmediatamente aguas debajo de la confluencia con el Arroyo de la Mina (right side of the Ñirihuau River Valley, immediately downstream from the confluence with the Arroyo de la Mina; Feruglio, 1941, p. 44; see also Aragón and Romero, 1984). The specimens collected by Feruglio were studied by Anne Fiori (1939), who referred them as belonging to the "Medio rio Nirihuau", and are housed in the Museo Geologico Giovanni Capellini, Bologna, Italia. It was Feruglio (1941, p. 45) who suggested the coincidence of both, the "198" and "Medio rio Ñirihuau" fossiliferous sites.

"Mina de Petróleo" is other site whose fossil flora was sampled by Feruglio (1941), and also studied by Fiori (1939). This locality is geographically close ( $5 \mathrm{~km}$ to the south) to Ñirihuau Medio (Fig. 1) and their outcrops are stratigraphically slightly below, but belonging all of them to the upper section of Nirihuau Formation (see geology and age below).

\subsection{Geology and age}

Stratigraphically, the fossiliferous levels exposed at Ñirihuau Medio belong to the upper member of Nirihuau Formation, more precisely at the Stage I of Paredes et al. (2009, fig. 7). This section consists of lowsinuosity fluvial and minor shallow lacustrine facies associations developed during an inter-eruptive volcaniclastic stage (Paredes et al., 2009). The complete profile of the Ñirihuau Formation (González Bonorino and

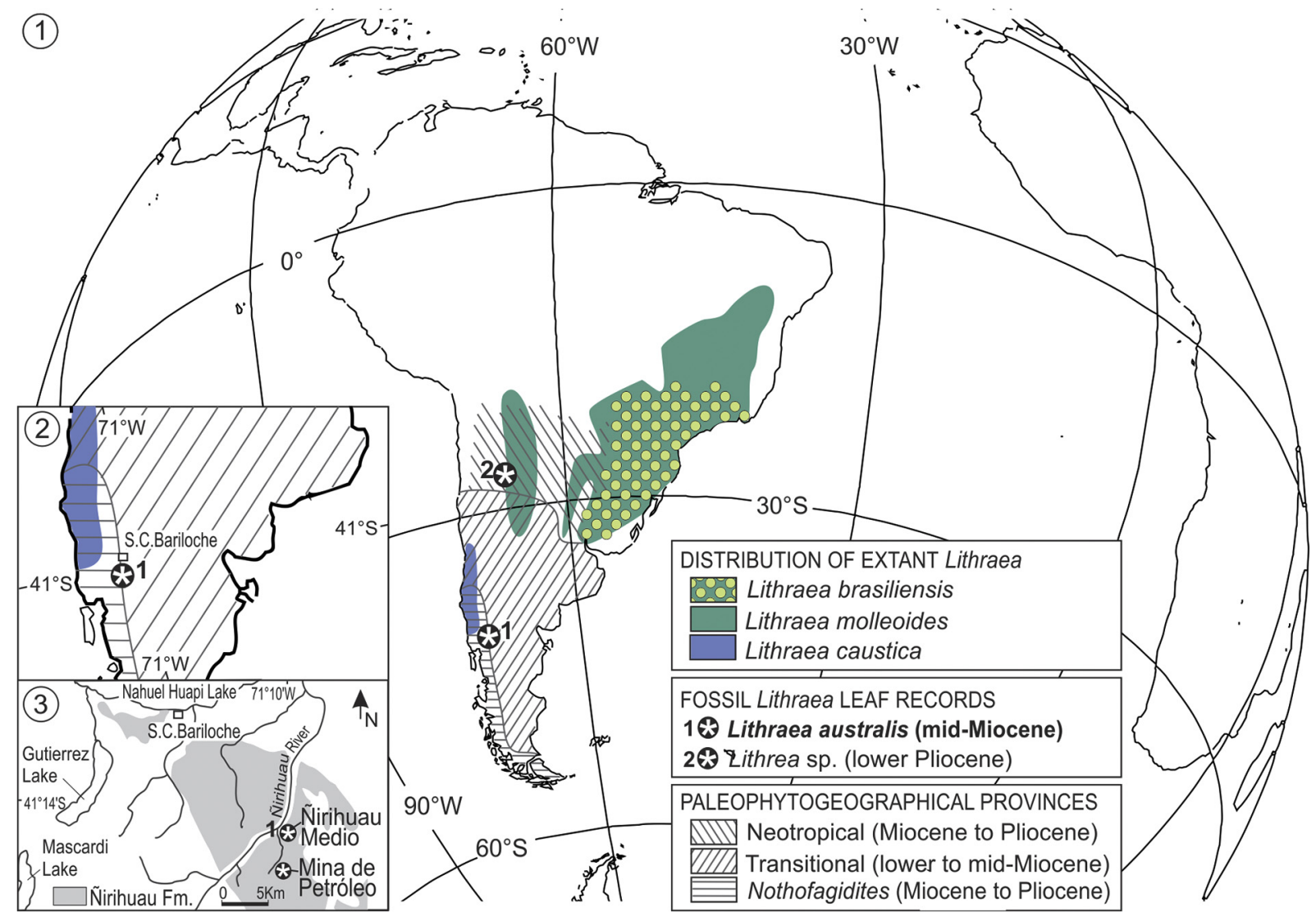

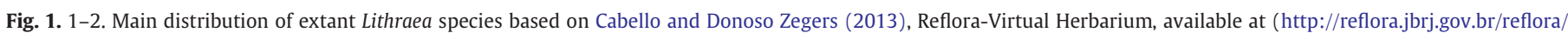

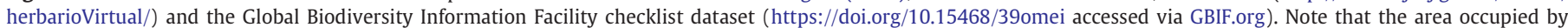

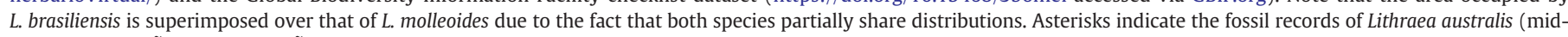

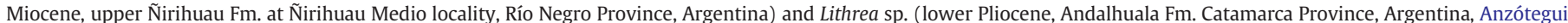

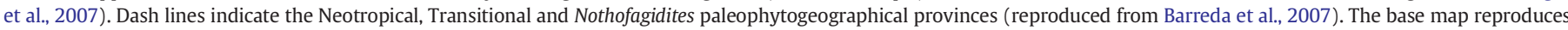

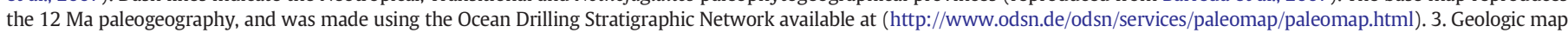
showing the Ñirihuau Medio and Mina the Petróleo localities (Río Negro Province, Argentina) and Ñirihuau Fm outcrops (gray areas, based on Giacosa et al., 2001). 
González Bonorino, 1978), deposited in the homonymous basin, comprises clastic and pyroclastic deposits and subordinated carbonates (Bechis et al., 2014, and references therein). Although this unit is predominantly continental, a marine episode has been identified in its middle member (Bechis et al., 2014, 2015). A recent study considering geochronologic dates, structural basin evolution and stratigraphic correlations (Bechis et al., 2015) concludes that the Nirihuau Formation was deposited mainly during the middle Miocene with its uppermost section (including the fossiliferous level of this study) reaching the upper Miocene (around 12-11 Ma).

\subsection{Floral assemblages from the upper section of the Nirihuau Formation}

The megafloral assemblage present in the upper section of the Nirihuau Formation has been scarcely studied in the past. Preliminary data on new collections (Passalia et al., 2016), as well as previous works (Berry, 1928; Fiori, 1939) show that it is dominated by nano- to microphyll angiosperm leaves, mostly with toothed margins. Nothofagaceae is the main component by richness and relative abundance, followed by probable Myrtaceae, Proteaceae and Berberidaceae, among others.

A palynological assemblage, recovered from the same megafloral level (Passalia et al., 2016), is also dominated by Nothofagus beech (fusca pollen type). Other woody angiosperm pollen, related to Winteraceae (Drymis type), Proteaceae, Myrtaceae and Anacardiaceae are present but in very low frequencies. Conifers are represented by podocarps (Podocarpidites spp.) and araucarian pollen (Araucariacites ssp.), leaves and probable cupressaceous branches. Fern spores exhibits a low richness and relative abundance in the assemblage. They are mainly represented by Dicksoniaceae (cf. Lophosoria), probable Blechnaceae and Pteridaceae (Pteris type). Pollen of herbaceous angiosperms belonging to Onagraceae, Malvaceae, Asteraceae and Gunneraceae occur in trace amounts, as well as swamp families as the Typhaceae. Brackish to fresh-water algae (Botryoccocus) are also recorded.

\subsection{Extant material}

For comparative purposes, leaves of the extant Anacardiaceae Lithraea molleoides (Vell) Engl. were sampled from a native specimen in Cruz de Piedra locality, on the western slope of the Sierras Centrales de San Luis, San Luis Province, Argentina. The Reflora-Virtual Herbarium (Forzza et al., 2015), available at http://reflora.jbrj.gov.br/reflora/ herbarioVirtual/, was consulted for leaf architectural features of Lithraea brasiliensis March. Additionally, the online database of cleared plant leaf images (Das et al., 2014), the Global Biodiversity Information Facility (https://www.gbif.org) and the Australian Tropical Rainforest Plants Edition 6 (http://www.anbg.gov.au/cpbr/cd-keys/rfk/index.html) were accessed for comparative data.

\subsection{Description terminology}

The angiosperm leaves were described following the Manual of Leaf Architecture (Ellis et al., 2009). However, some terminologies used, such as those referring to the texture, vein course, relative thickness (gauge) of veins or angle of divergence of secondaries were taken from Hickey (1973). Specimens were observed using a Nikon SMZ800 stereomicroscope and photographed with a Nikon DS-Fi1 and a Sony DSC-H7 digital camera. Systematic classification follows the Angiosperm Phylogeny Group system (APG IV, 2016).

\section{Systematic paleontology}

Order: SAPINDALES Juss. ex Berchtold et Presl 1820

Family: ANACARDIACEAE R. Brown, 1818

Genus: Lithraea Miers ex Hook. et Arn
Type species: Lithraea caustica (Molina) Hook. et Arn

Lithraea australis (Berry) Passalia, Caviglia et Vera, comb. nov.

1928. Zamia australis Berry, USNM 37857, in Berry, 1928, p. 11-12,

pl. 2, fig. 1

?1939. Filicites sp. 1, in Fiori, 1939, p. 56, tav. I, fig. 2

Holotype: USNM 37857 (Plate I)

Type locality: Ñirihuau Medio, Ñirihuau River, Río Negro Province, Argentina

Stratigraphic horizon: Upper section of the Ñirihuau Formation Age: Middle Miocene

Additional specimens: MAPBAR 6604-6608; 6609-6614; BAFC-Pb 17416-17419.

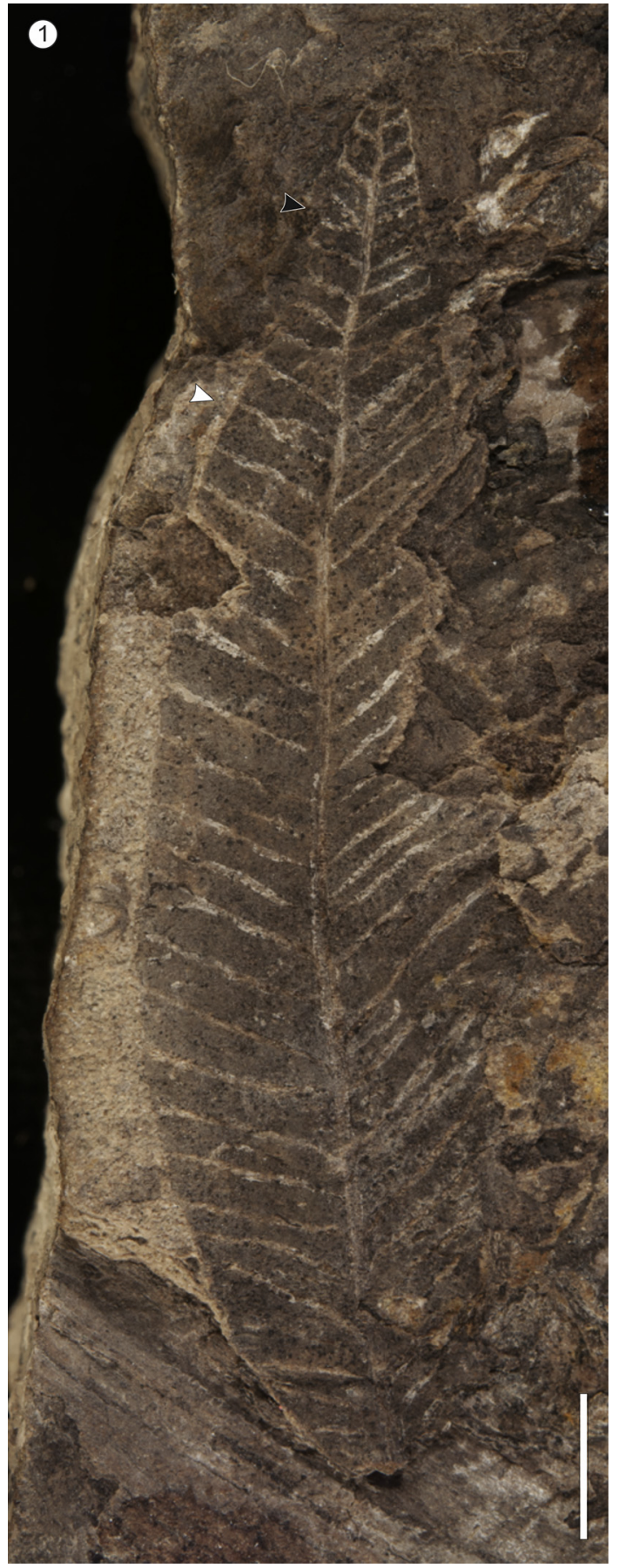

Plate I. 1-2. Lithraea australis (USNM 37857), holotype. Specimen figured by Berry (1928 in pl. 2, fig. 1). Note secondaries exmedially (black arrowhead) and admedially (white arrowhead) forked. Scales $=0.5 \mathrm{~cm}$. 
Description: Microphyllous leaves, with marginal attachment, apparently sessile. Laminar shape variable, including forms oblong (6608, 37857, Plate II, 1), elliptic (Plate II, 2) and obovate (Plate I,
5). Blade medially mostly symmetrical to slightly asymmetrical. Leaf margin untoothed. Lamina dimensions $3-4 \mathrm{~cm}$ long and $0.5-1 \mathrm{~cm}$ wide (ratio L:W typically 4-7:1). Apex angle acute (mostly between


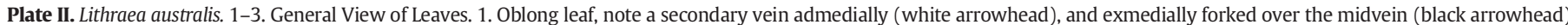

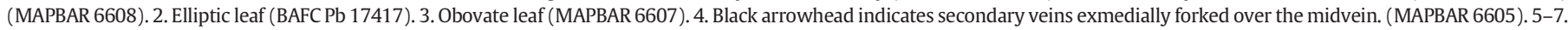

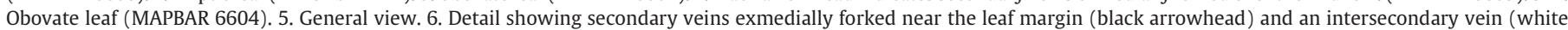
arrowhead). 7. Detail of the foliar base showing numerous secondaries admedially forked (one of them indicated by a black arrowhead). Scales $1-5=0.5 \mathrm{~cm}, 6-7=0.1 \mathrm{~cm}$. 
25 and $50^{\circ}$ ), straight or slightly convex in shape. Base acute (mostly between 25 and $40^{\circ}$ up to $60^{\circ}$ ), typically cuneate. Primary venation pinnate. Midvein with stout to typically massive size. Major secondaries craspedodromous. Secondary veins thick and mostly with a straight course, although slightly curved and recurved are also observed. Secondaries excurrently attached to midvein in uniform moderate to wide angles (typically between 50 and $70^{\circ}$ up to near $90^{\circ}$ ). Secondaries numerous ( 8 per centimeter in average) regularly spaced, reaching the margin where they join with a marginal secondary vein (Plate III, 5). Secondaries mostly unbranched, although a single exmedial dichotomy may occur near the margin but without decrease gauge by attenuation as occur in cladodromous venation type (e.g. Plates II, 6 and III, 2, 5-6). In other cases, a single exmedial dichotomy is observed in the arising of the secondaries over the midvein (e.g. Plates I and II, 1, 4, 7) as well as secondaries with a single admedial dichotomy (e.g. Plates I and II, 1). Intersecondary veins may be present, although in a very low frequency (less than one per intercostal area, e.g. Plates II, 6 and III, 4). Intersecondaries disposed parallel to the major secondaries and as thick as them. Venation of tertiary and higher order not preserved. No epidermal details are identified in the fine carbonaceous film that covers the fossil leaves.

Remarks: In the absence of conclusive evidence, the specimens are here treated as leaves, but it is not ruled out that they could have consisted of sessile leaflets of a compound leaf. The specimen MAPBAR6612 (Plate III, 1-3) consists of an anomalous (atypical) form with more and less rounded apex, but conserves the venation features that characterize Lithraea australis. Additionally, this specimen (MAPBAR6612) exhibits a strong medial asymmetry, a feature common in lateral leaflets of pinnately compound leaves. An outstanding feature
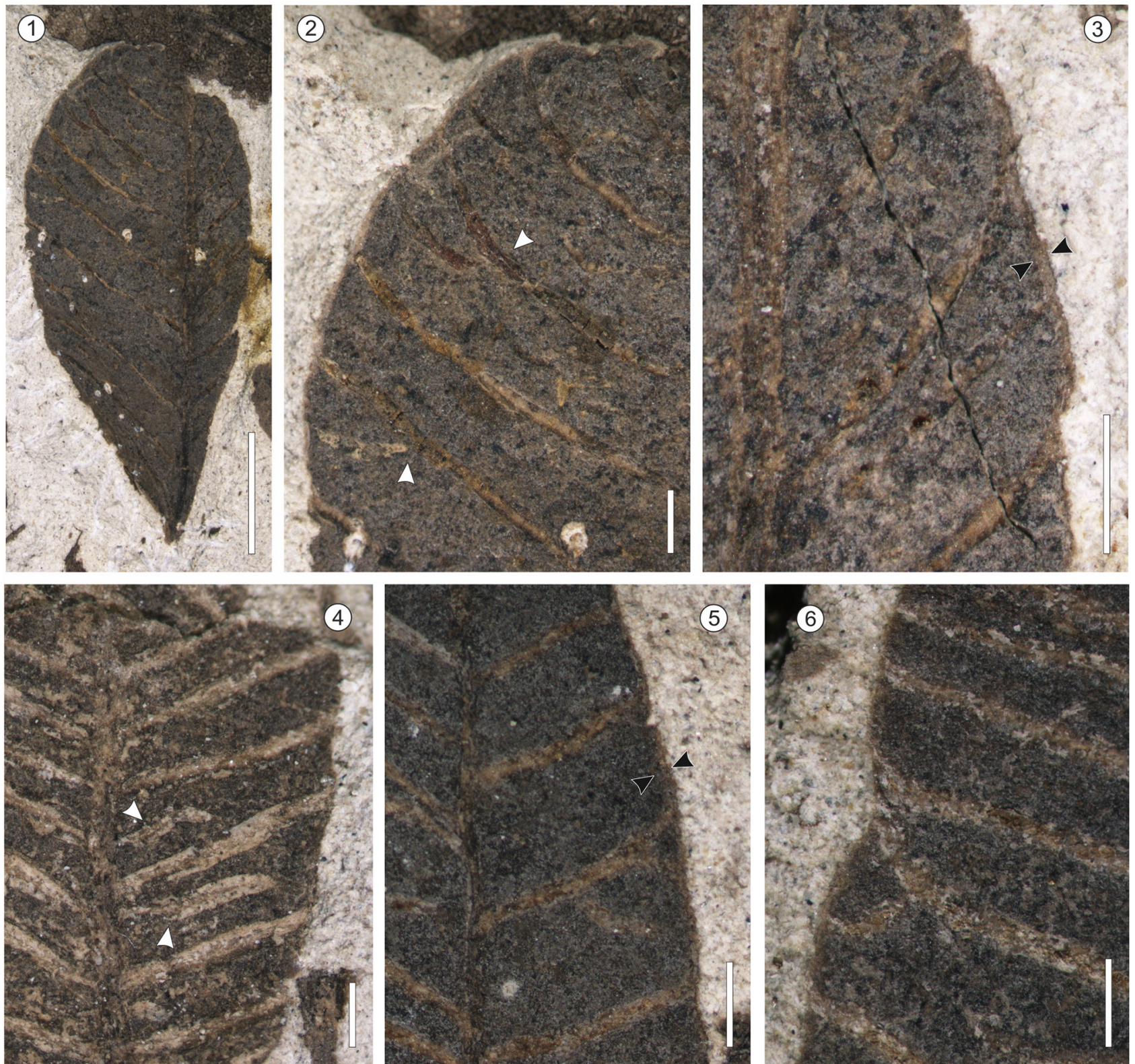

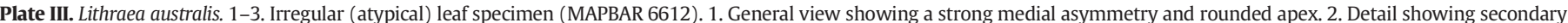

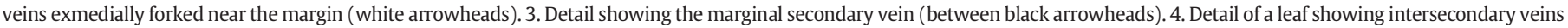

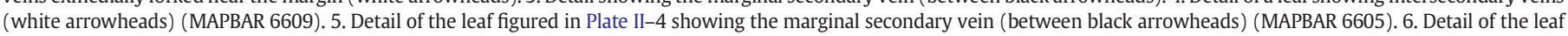
figured in Plate II-5 (MAPBAR 6604). Scales $1=0.5 \mathrm{~cm}, 2-6=0.1 \mathrm{~cm}$ 
of this species is the great relative thickness (gauge) of its secondary veins.

\section{Discussion}

\subsection{Previous leaf fossil records here included in Lithraea australis}

Berry (1928) published a number of fossil ferns, gymnosperms and angiosperms coming from mid-Cretaceous and Cenozoic deposits of Patagonia, including a species described as Zamia australis Berry (1928, pl. 2 fig. 1). The author interpreted this specimen as a pinnate frond and concluded that is a leaf of Cycadaceae (currently Zamiaceae). However, a review of Berry's original material (Plate I), supported by new specimens (Plates II and III) clearly shows that what the author interpreted as pinnules (= leaflets) are in fact intercostal areas of an angiosperm leaf. Furthermore, the areas considered by Berry as spaces between leaflets corresponds really to secondary veins of a leaf. The interpretation of Berry of this specimen is curious given that even in his material there are both exmedially and admedially branched secondary veins (see arrowheads in Plate I), features not reflected by the author in their line draw. There is no doubt that the specimens of Berry and the new ones recorded here belong to the same species and are included in Lithraea australis.

A few years after Berry's work, Anna Fiori briefly described a leaf fragment as Filicites sp. 1 (Fiori, 1939 p. 56, tav. 1, fig. 2). This specimen comes from the locality Mina de Petróleo (see Materials and Methods). In his description, Fiori mentions: Very long pinnule fragment in relation to the width and progressively narrowing towards the apex..., ....untoothed margin. Strong medial nerve, right. Visible lateral nerves, straight at 55-63 ${ }^{\circ}$ respect to the midvein, length/width of the fragment $27 / 8 \mathrm{~mm}$. Fiori also states that "The fragment is very reminiscent of the Blechnum antediluvianum Engelhardt (1891, Eocene of central Chile) of which it would represent the apical portion of the pinnula, but here the median nerve appears much more robust". The original specimen of Fiori, housed at Museo di Bologna, Italia, has not yet been located. However, by the description and illustration Filicites sp. 1 of Fiori (1939) is here tentatively referred to Lithraea australis.

\subsection{Botanical affinity}

Pinnately veined leaves/leaflets with secondaries fused in a marginal secondary vein are features recognized in extant species of different families (e.g. Alstonia congenis, Apocynaceae, Machaerium biovulatum, Fabaceae; Ouratea reflexum, Ochnaceae). A combination of characters identified in $L$. australis is also present in extant representatives of Anacardiaceae, allowing to postulate affinities with this family. These features include: elongate blade shape, base typically cuneate, margin unthooted to "subcrenulate," midvein with stout to massive size, secondaries numerous, parallel, regularly and closely spaced in uniform and wide angles, mostly unbranched but occasionally exmedially and/ or admedially forked (e.g. Lithraea molleoides, L. brasiliensis, Abrahamia sericea, A. grandidieri) or typically cladodromous (e.g. A. itremoensis, Heeria insignis, $H$. pulcherrima, L. caustica, Ozoroa mucronata, O. obovata, O. reticulata, O. paniculosa; Protorhus buxifolia), joined to a marginal secondary vein and intersecondaries commonly presents and robust. Among extant Anacardiaceae, L. australis exhibits a marked similarity with leaves/leaflets of Lithraea as discussed in detail below.

The genus Lithraea Miers ex Hook. et Arn. (Anacardiaceae) consists of perennial shrubs and trees included in three accepted South American species with disjunct distribution (absent along the arid diagonal, see Fig. 1): L. molleoides (Vell.) Engl. (Central-northern Argentina, Southern Brazil, Bolivia, Paraguay and Uruguay); L. brasiliensis March. (North-easter Argentina, Uruguay and South-eastern Brazil) and L. caustica (Molina) Hook et Arn. (Central Chile) (Muñoz, 1999; Zuloaga et al., 2008). Main physiognomical leaf features of extant Lithraea species are summarized in the Table 1. Lithraea molleoides and
L. brasiliensis have leaves that show resemblance in shape and venation to those of Lithraea australis. This fact is especially notably with L. molleoides, which is compared in detail with the fossil species.

Lithraea molleoides (syn. Schinus molleoides Vell., S. ternifolius Hook., S. brasiliensis Marchand ex Cabrera, Lithraea molleoides (Vell.) Engl. var. lorentziana Hieron. ex Lillo, L. ternifolia (Hook.) F.A. Barkley, L. gilliesii Griseb. In Zuloaga et al., 2008) is a tree of medium height, with simple but typically pinnately compound leaves, 3 or 5 (up to 7) leaflets (Plate IV, 1-3). Based on previous work (Martínez-Millán and Cevallos-Ferriz, 2005; Mercado et al., 2014) and own observations, some architectural foliar features of L. molleoides are the following: Leaflets cartaceous to coriaceous of microphyll size, the terminal leaflet typically somewhat larger than the laterals, $3-7 \mathrm{~cm}$ long and $\mathrm{L}: \mathrm{W}$ ratio around 4:1; apical leaflet sessile or with a short petiolule; lateral leaflet opposites, sessile. Additionally, the laminar shape includes forms elliptic as well as ovate or oblong, with apex acute, typically straight or slightly convex, base acute cuneate to decurrent in apical leaflets and untoothed margin (Plate IV, 4-5, 8, 9-10). These features are essentially similar to those of $L$. australis. Some leaflets, as well as simple leaves, develop an anomalous (atypical) laminar shape with more and less rounded to emarginate apex (Plate IV, 6-7). This last feature is comparable to that observed in some specimens of $L$. australis (see Plate III, 1-3). The venation of $L$. molleoides, as in the fossil species, is pinnate with numerous secondaries excurrently attached to the stout midvein at uniform angles. Secondaries are mostly unbranched, although single admedial and exmedial forks may occur, features also shared with $L$. australis.

The secondaries in L. molleoides (and also in L. brasiliensis) are joined in a marginal secondary vein (Plate IV, 12). At the junction point of each secondary vein with the marginal vein, there is a shallow incision in the leaf margin, giving it a "sub-crenulate" appearance (Plate IV, 11). This feature seems to be present also in L. australis, although it is not as evident as in L. molleoides. Following Ellis et al. (2009), the major secondary vein framework of $L$. molleoides corresponds to the craspedodromous type. Mercado et al. (2014) considered the perimarginal vein as intramarginal and then describes the secondaries as brochidodromous type. Previously, Martínez-Millán and Cevallos-Ferriz (2005) following the former terminology proposed by the Leaf Architecture Working Group (1999) described the secondary vein type as intramarginal. In spite of differences in the consideration of the type of the perimarginal vein (marginal or intramarginal) and then the type of secondary vein framework interpretation (craspedoromous or brochidodromous) the venation network of $L$. molleoides and $L$. australis display the same pattern. The gauge, disposition and frequency of intersecondaries (Plate IV, 11) are other features shared by both extant and fossil species.

An outstanding feature of $L$. australis is the relative thickness (gauge) of the secondary veins, even greater than the observed in the extant Lithraea species. The presence of thick secondaries in L. australis, could be the result of the development of some type of mechanical tissue (e.g. sclerenchyma, collenchyma) surrounding the vascular strand, as well as the presence of secretory ducts or both. In this sense, Metcalfe and Chalk (1950) pointed out the presence of secretory channels and ducts as an anatomical feature of Anacardiaceae leaves. In particular, L. molleoides leaves show secondary veins formed by vascular bundles surrounded by a parenchymatous sheath, phloem frequently interrupted by schizogenous channels and midrib with abundant fibers and a ring or cap of schlerenchymatous cells at phloem level (MartínezMillán and Cevallos-Ferriz, 2005; Mercado et al., 2014). Although the secondary veins of $L$. australis have a relative thickness greater than the veins in L. molleoides, in both cases, the gauge of secondaries remains constant throughout their course from the midvein to the leaf margin, a feature also shared with $L$. brasiliensis.

Tertiary veins of $L$. molleoides display a reticulate irregular or admedially ramified pattern (Mercado et al., 2014). Tertiaries and higher order veins are thin, embedded in a relatively thick mesophyll and consequently are only visible in cleared leaves. This would explain the fact that they do not appear preserved in the fossil species. 
Table 1

Leaf architecture comparison between the fossil species Lithraea australis and the extant Lithraea species.

\begin{tabular}{|c|c|c|c|c|c|c|c|c|c|c|c|c|}
\hline & \multirow{2}{*}{$\begin{array}{l}\text { Leaf } \\
\text { organization }\end{array}$} & \multicolumn{4}{|l|}{ Leaf/leaflet } & \multirow{2}{*}{$\begin{array}{l}\text { Venation main } \\
\text { features }\end{array}$} & \multirow[t]{2}{*}{ Midvein } & \multicolumn{3}{|l|}{ Secondary veins } & \multirow{2}{*}{$\begin{array}{l}\text { Intersecondary } \\
\text { veins }\end{array}$} & \multirow{2}{*}{$\begin{array}{l}\text { Tertiary } \\
\text { veins }\end{array}$} \\
\hline & & $\begin{array}{l}\text { Long and } \\
\text { (L:W } \\
\text { ratio) }\end{array}$ & $\begin{array}{l}\text { Blade shape and } \\
\text { margin }\end{array}$ & Apex angle and shape & $\begin{array}{l}\text { Base } \\
\text { angle and } \\
\text { shape }\end{array}$ & & & $\begin{array}{l}\text { Attachment to } \\
\text { the midvein }\end{array}$ & $\begin{array}{l}\text { Relative gauge and } \\
\text { course }\end{array}$ & Number & & \\
\hline $\begin{array}{l}\text { Lithraea } \\
\text { australis }\end{array}$ & Unknown & $\begin{array}{l}3-4 \mathrm{~cm} \\
(4-7: 1)\end{array}$ & $\begin{array}{l}\text { Variable } \\
\text { (elliptic, oblong, } \\
\text { obovate), } \\
\text { untoothed, } \\
\text { possibly } \\
\text { "sub-crenulate" }\end{array}$ & $\begin{array}{l}\text { Acute, straight or slightly } \\
\text { convex }\end{array}$ & $\begin{array}{l}\text { Acute, } \\
\text { cuneate }\end{array}$ & $\begin{array}{l}\text { Pinnate, } \\
\text { craspedodromous } \\
\text { with secondaries } \\
\text { joined in a } \\
\text { marginal } \\
\text { secondary vein }\end{array}$ & $\begin{array}{l}\text { Stout to } \\
\text { massive }\end{array}$ & $\begin{array}{l}\text { Excurrently, } \\
\text { uniform angle, } \\
\text { moderate to } \\
\text { wide }\left(50-70^{\circ}\right. \\
\left.\text { up to near } 90^{\circ}\right)\end{array}$ & $\begin{array}{l}\text { Very thick, mostly } \\
\text { straight and } \\
\text { unbranched, but } \\
\text { also admedially and } \\
\text { exmedially forked }\end{array}$ & $\begin{array}{l}8 \text { veins per } \mathrm{cm} \\
\text { in average, } \\
\text { regularly } \\
\text { spaced }\end{array}$ & $\begin{array}{l}\text { Present, less than } \\
\text { one per intercostal } \\
\text { area, parallel to the } \\
\text { major secondaries } \\
\text { and thick }\end{array}$ & Unpreserved \\
\hline $\begin{array}{l}\text { Lithraea } \\
\quad \text { molleoides }\end{array}$ & $\begin{array}{l}\text { Simple, but } \\
\text { typically } \\
\text { pinnately } \\
\text { compound } \\
\text { with } 3,5 \text { up to } \\
7 \text { leaflets }\end{array}$ & $\begin{array}{l}3-7 \mathrm{~cm} \\
(4: 1)\end{array}$ & $\begin{array}{l}\text { Variable } \\
\text { (elliptic, ovate, } \\
\text { oblong), } \\
\text { untoothed, } \\
\text { "sub-crenulate" }\end{array}$ & $\begin{array}{l}\text { Acute, straight or slightly } \\
\text { convex and commonly } \\
\text { mucronate }\end{array}$ & $\begin{array}{l}\text { Acute, } \\
\text { cuneate to } \\
\text { decurrent } \\
\text { in apical } \\
\text { leaflets }\end{array}$ & $\begin{array}{l}\text { Pinnate, } \\
\text { craspedodromous } \\
\text { with secondaries } \\
\text { joined in a } \\
\text { marginal } \\
\text { secondary vein }\end{array}$ & Stout & $\begin{array}{l}\text { Excurrently, } \\
\text { uniform angle, } \\
\text { moderate to } \\
\text { wide (mostly } \\
\text { about } 50-60^{\circ} \text { ) }\end{array}$ & $\begin{array}{l}\text { Moderate, mostly } \\
\text { straight and } \\
\text { unbranched, but } \\
\text { also admedially and } \\
\text { exmedially forked }\end{array}$ & $\begin{array}{l}56 \text { veins per } \\
\mathrm{cm} \text { in average, } \\
\text { regularly } \\
\text { spaced }\end{array}$ & $\begin{array}{l}\text { Present, less than } \\
\text { one per intercostal } \\
\text { area, parallel to the } \\
\text { major secondaries } \\
\text { and thick }\end{array}$ & $\begin{array}{l}\text { Typically } \\
\text { ramified }^{\mathrm{a}}\end{array}$ \\
\hline $\begin{array}{l}\text { Lithraea } \\
\quad \text { brasiliensis }\end{array}$ & Simple & $\begin{array}{l}4-8 \mathrm{~cm} \\
(2,5-4,5: 1)\end{array}$ & $\begin{array}{l}\text { Variable } \\
\text { (elliptic, oblong, } \\
\text { obovate), } \\
\text { untoothed, } \\
\text { "sub-crenulate" }\end{array}$ & $\begin{array}{l}\text { Variable, acute and } \\
\text { straight to convex or } \\
\text { obtuse and rounded or } \\
\text { reflex and emarginate; } \\
\text { mucronate in all cases }\end{array}$ & $\begin{array}{l}\text { Acute, } \\
\text { cuneate to } \\
\text { decurrent }\end{array}$ & $\begin{array}{l}\text { Pinnate, } \\
\text { craspedodromous } \\
\text { with secondaries } \\
\text { joined in a } \\
\text { marginal } \\
\text { secondary vein }\end{array}$ & Stout & $\begin{array}{l}\text { Excurrently, } \\
\text { uniform angle, } \\
\text { moderate to } \\
\text { wide (mostly } \\
\text { about } 50-60^{\circ} \text { ) }\end{array}$ & $\begin{array}{l}\text { Moderate, mostly } \\
\text { straight and } \\
\text { unbranched, but } \\
\text { also admedially and } \\
\text { exmedially forked }\end{array}$ & $\begin{array}{l}45 \text { veins per } \\
\mathrm{cm} \text { in average, } \\
\text { regularly } \\
\text { spaced }\end{array}$ & $\begin{array}{l}\text { Present, less than } \\
\text { one per intercostal } \\
\text { area, parallel to the } \\
\text { major secondaries } \\
\text { and thick }\end{array}$ & $\begin{array}{l}\text { Typically } \\
\text { ramified }\end{array}$ \\
\hline $\begin{array}{l}\text { Lithraea } \\
\text { caustica }\end{array}$ & Simple & $\begin{array}{l}4-6 \mathrm{~cm} \\
(2: 1)\end{array}$ & $\begin{array}{l}\text { Typically } \\
\text { elliptic, } \\
\text { untoothed, } \\
\text { erose }\end{array}$ & $\begin{array}{l}\text { Acute, Typically convex, } \\
\text { but also rounded, } \\
\text { frecuently mucronate or } \\
\text { retuse, uncommonly } \\
\text { emarginate }\end{array}$ & $\begin{array}{l}\text { Acute, } \\
\text { cuneate }\end{array}$ & $\begin{array}{l}\text { Pinnate, } \\
\text { cladodromous } \\
\text { type } I^{\mathrm{a}}\end{array}$ & Stout & $\begin{array}{l}\text { Excurrently, } \\
\text { angle } \\
\text { increasing } \\
\text { proximally }^{\mathrm{a}}\end{array}$ & $\begin{array}{l}\text { Moderate, mostly } \\
\text { straight, exmedially } \\
\text { ramify }\end{array}$ & $\begin{array}{l}2-2,5 \text { veins per } \\
\mathrm{cm} \text { in average, } \\
\text { regular to } \\
\text { frequently } \\
\text { irregularly } \\
\text { spaced }\end{array}$ & $\begin{array}{l}\text { If present, less than } \\
\text { one per intercostal } \\
\text { area, thin }{ }^{\mathrm{a}}\end{array}$ & $\begin{array}{l}\text { Typically } \\
\text { ramified, but } \\
\text { also } \\
\text { percurrent }^{\mathrm{a}}\end{array}$ \\
\hline
\end{tabular}

${ }^{a}$ From Martínez-Millán and Cevallos-Ferriz (2005) 

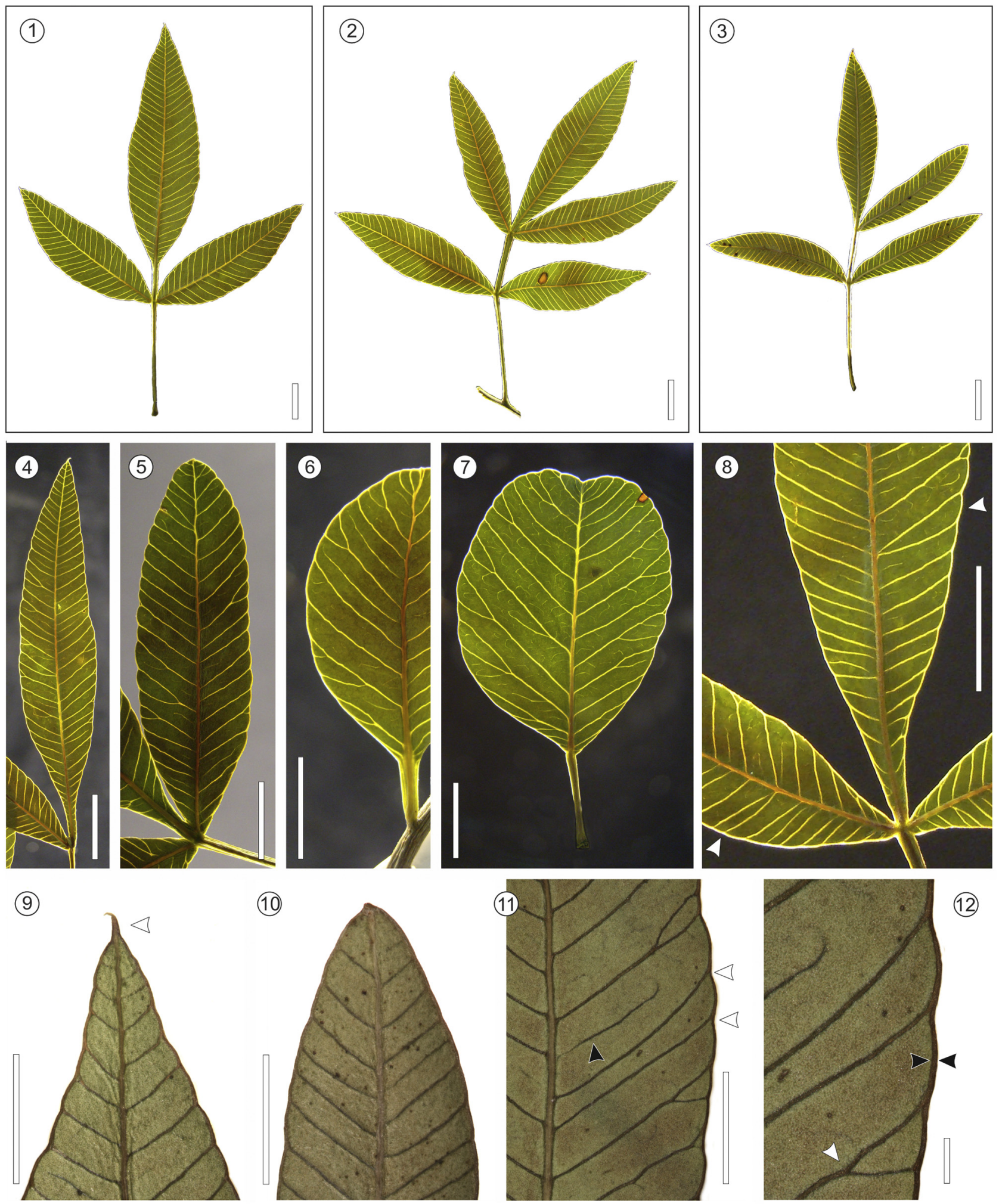

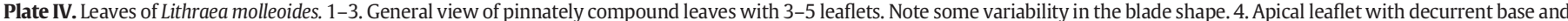

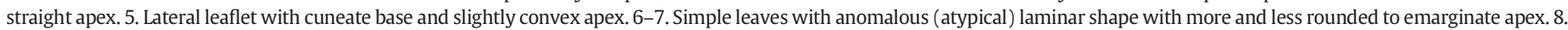

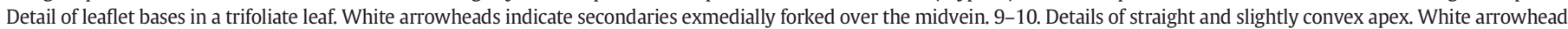

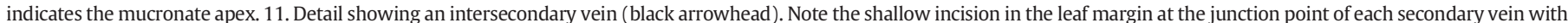

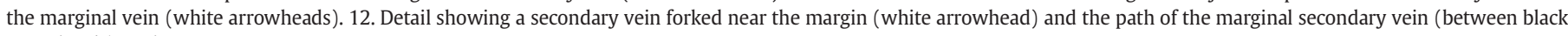
arrowheads). Scales $1-10=1 \mathrm{~cm}, 11=0.5 \mathrm{~cm}, 12=0.1 \mathrm{~cm}$.

Some leaves of $L$. molleoides show aberrant or anomalous blade development (Plate IV, 6-7), that result in laminar shape comparable to those found in some specimens of L. australis (Plate III, 1-3).
The leaves of $L$. australis also have some resemblance to those of the extant Lithraea brasiliensis. They are simple, petiolate, with variable blade shape (elliptic, oblong or obovate) and untoothed margin. The 
base is acute cuneate to decurrent. The apex angle and shape is variable: acute and straight to convex; obtuse and rounded, or alternatively reflex and emarginate, but in all cases shortly mucronate. In their variability there are elongate forms similar to the fossil ones. Secondary veins are numerous and also displayed follow a framework comparable to those of $L$. australis.

In contrast to the similarities observed among $L$. australis and the extant $L$. molleoides and $L$. brasiliensis, the leaves of Lithraea caustica are clearly distinguished both in blade shape and the major secondary vein framework (cladodromous) (Martínez-Millán and CevallosFerriz, 2005; Forzza et al., 2015).

According to Weeks et al. (2014), Lithraea is a relatively derived genus within Anacardiaceae phylogeny, with a Lithraea/Mauria crown group as older as early Miocene ( $18 \mathrm{Ma}$, Weeks et al., 2014). This supports the probably presence of a Lithraea species in the mid-Miocene paleocommunity of Nirihuau.

The neotropical genus Mauria, sister clade of Lithraea molleoides, includes species with cladodromous type I venation as in Lithraea caustica (Martínez-Millán and Cevallos-Ferriz, 2005) and then clearly distinguished from those of $L$. molleoides, $L$. brasiliensis and the fossil L. australis. In fact, Silva-Luz et al. (2019) recover Lithraea caustica as the basalmost member of the genus, suggesting that the craspedodromous condition may be a synapomorphy of the L. molleoides-L. brasiliensis clade.

Summarizing, the fossil leaves described here exhibit features that suggest a close relationship with the extant genus Lithraea, being probably more related with the $L$. molleoides $-L$. brasiliensis clade, than to L. caustica, and thus probably nested within the genus Lithraea. The divergence time estimates for this genus (Weeks et al., 2014), and their South American current distribution also fit with this botanical affinity. Although no fertile organs (flowers, fruits) attached, or at least recognized in the same assemblage have been found, it is here preferred to refer these remains to the extant genus Lithraea, instead of erecting a new fossil genus for encompassing them.

\subsection{Extant distribution of L. molleoides, paleonvironmental and paleophytogeographical considerations}

Lithraea molleoides is an arboreal species, distributed along a longitudinal north-south strip from central to northern Argentina (Fig. 1), in the Chaco-Serrano eco-region of Burkart et al. (1999). In this region it acquires a typical orophilous habit (= that grow in mountain slopes) reaching up to $2100 \mathrm{~m}$ of altitude (Demaio et al., 2015) and constitutes the climax community being, with Schinopsis marginata Engl. (Anacardiaceae), the dominant species. Its geographic distribution extends to northeast Argentina in the Chaco Húmedo and it is a secondary species in the marginal jungles of the Selva Paranaense eco-region (Demaio et al., 2015). Its geographic distribution also includes the montane areas of Bolivia, occupying the East Paraguay, Uruguay and the Cerrado vegetation, a tropical savanna eco-region of Brazil (Muñoz, 2000). The leaves of $L$. molleoides display meso- and xeromorphic anatomical features with structural variations that show their high capacity of tolerance to different environmental conditions and soil types (Arambarri et al., 2011).

As mentioned above, the leaves of $L$. molleoides have a high number of features shared with $L$. australis and consequently may be considered a modern analogue. In this sense, the presence of $L$. molleoides may be suggesting some xerophytic environmental conditions, at least seasonally, prevailing during the deposition of the upper section of the Nirihuau Formation. This is in accordance with the reduced foliar areas that characterize the angiosperm leaf records of this stratigraphic level (Romero and Dibbern, 1984; Passalia et al., 2016).

During the mid-Miocene, the humid forested communities from eastern Patagonia were replaced by open habitat ecosystems (Barreda and Palazzesi, 2014). In contrast, those from the westernmost areas retained their arboreal structure and main families represented, occupying a progressively narrow north-south area from 35 to $55^{\circ}$ south latitude. These communities are currently part of the eco-region known as Patagonian Forests (=Subantartic or Andean-Patagonian Forest). The palynological composition of these Miocene western forests allowed them to be characterized as the paleophytogeographic "Nothofagidites Province" (e.g. Romero, 1993; Barreda et al., 2007), being mainly composed of subantarctic elements such as Nothofagaceae, Araucariaceae, Podocarpaceae, Proteaceae, along with some lineages of Myrtaceae, and without presence of other taxa typical of the extant "Dominio Chaqueño" (in the sense of Cabrera, 1976), such as Anacardiaceae and Fabaceae. During the early-mid Miocene, the "Nothofagidites Province" limited to the East with the "Transitional Province," which was also characterized by subantarctic elements but with participation of taxa from the extant "Dominio Chaqueño" (Barreda et al., 2007). The floral communities preserved in the upper section of Ñirihuau Formation, include all the typical families of the "Nothofagidites Province." However, the recognition of a L. molleoides closely related species, suggests that these communities probably were part of the "Transitional Province" or at least occupied the ecotone between both, Nothofagidites and Transitional Provinces. This is in accordance with a preliminary palynological report from the same level from where $L$. australis was recovered, that includes (although in a low relative abundance) elements typical of the "Transitional Province," as Tricolpites trilobatus Mildenhall et Pocknall (Convolvulaceae) and Striatricolporites sp. (Anacardiaceae) (Passalia et al., 2016). In spite of these preliminary suppositions, more and detailed studies on the Ñirihuau flora are necessary to shed light in this direction.

\subsection{Cenozoic Anacardiaceae leaf records from South America}

Extant (Astronium, Lithraea, Schinus, Schinopsis) and fossil (Anacardites Saporta, Roophyllum Dusén) genera have been employed to describe fossil leaves presumably attributable to the Anacardiaceae from Cenozoic (mainly middle Eocene-Miocene) deposits of Argentina and Chile (Dusén, 1899; Berry, 1925, 1928, 1937, 1938; Hünicken, 1967; Troncoso, 1992; Anzótegui, 1998, 2004; Anzótegui and Herbst, 2004; Anzótegui et al., 2007; Anzótegui and Aceñolaza, 2008; Césari et al., 2015; Vento and Prámparo, 2018; Panti, 2018). Other extant genera as Duvaua (=Schinus), Spondias and Tapiria have been also employed to includes Paleo-Neogene leaf record of Bolivia, Brazil and Venezuela (Berry, 1924, 1939a, 1939b). However, there is little justification for including some of these South American fossils in the Anacardiaceae, and a critical review is needed to corroborate their affinities.

There are no diagnoses for the fossil genera Anacardites and Roophyllum. Concerning Anacardites, Berry (1938) states that it is useful for "fossil members of this family (Anacardiaceae) whose generic affinity was undeterminable." In fact, the genus has been employed for a variety of leaves/leaflets with toothed (e.g. A. pichileufuensis Berry) as well as untoothed margins (e.g. A. brittoni Berry). Similarly, the genus Roophyllum, previously proposed to describe leaves from the upper Eocene of southern Chile, includes two species with very different features. While one of them ( $R$. nordenskjöldi Dusén) consists of simple, lanceolate leaves with untoothed margins and brochidodromous major secondary veins; the other species ( $R$. serratum Dusén) includes oncepinnately compound leaves (odd) with serrate margin (teeth with deep sinuses) and craspedodromous major secondary veins that Dusén (1899) found to be similar to those of the extant genus Rhus.

Berry (1928) described Anacardites (?) patagonicus from the same locality as Lithraea australis. There are clear differences between these species, mainly in the development of major secondary veins.

Among these previous fossil records of Anacardiaceae, those described as Lithrea sp. (= Lithraea) from lower Pliocene deposits of northwestern Argentina (Anzótegui et al., 2007, see Fig. 1) stands out for their resemblance with $L$. australis. Features in common include: size, laminar length: maximum width ratio and shape; the presence of numerous 
secondary veins simple or forked near the margin and scarce intersecondaries disposes parallel to the secondaries. Both species would seem closely related although Lithrea sp. can be separated mainly by lacking a marginal secondary vein (Anzótegui et al., 2007).

\section{Conclusions}

A review of fossil leaves originally referred by Berry (1928) to the cycad Zamia australis Berry, and the collection of more specimens from the same fossiliferous levels, allowed a reinterpretation of this taxon. Features observed in these remains allow its placement in the family Anacardiaceae, and the combination, Lithraea australis (Berry), is here proposed to encompass these remains. Other remains, identified by Fiori (1939) as Filicites sp. are tentatively included in this taxon. Lithraea australis shows great similarities with the leaves of the extant species Lithraea molleoides (Vell.) Engl. (Anacardiaceae). The time of phylogenetic divergence estimated to the genus Lithraea and their South American current distribution also fit with this botanical affinity.

From a paleophytogeographic point of view, the recognizing of a L. molleoides closely related species suggest that the plant communities of the upper section of the Nirihuau Formation were part of the "Transitional Province," or at least constituted the ecotone between it and the "Nothofagidites" Province.

\section{Acknowledgements}

For land access to Ñirihuau deposits, we thank Jorge Calvo (Estancia El Desafío) and Secretaría de Cultura, Río Negro Province. We thank the American Museum of Natural History and Peter Wilf for providing photographs of the fossil collection of Edward Berry. Thanks are extended to Marian Tanuz for granting access to the paleobotanical collection of the Facultad de Ciencias Exactas y Naturales of the Universidad de Buenos Aires. We also thank Maria Angélica Gómez for providing extant leaves of Lithraea molleoides and journal Editor and the anonymous Reviewers for their critical and detailed comments and suggestions. This work was supported by ANPCyT (PICT-2602).

\section{References}

Anzótegui, L.M., 1998. Hojas de angiospermas de la Formación Palo Pintado, Mioceno superior, Salta, Argentina. Parte I: Anacardiaceae, Lauraceae y Moraceae. Ameghiniana $35,25-32$.

Anzótegui, L.M., 2004. Megaflora de la Formación Chiquimil, (Mioceno Superior), en los valles de Santa María y Villavil, provincias de Catamarca y Tucumán, Argentina. Ameghiniana 41, 303-314.

Anzótegui, L.M., Aceñolaza, P., 2008. Macrofloristic assemblage of the Paraná Formation (Middle-Upper Miocene) in Entre Ríos (Argentina). Neu. Jb. Geol. Paläont., Abh. 248, 159-170.

Anzótegui, L.M., Herbst, R., 2004. Megaflora (hojas y frutos) de la Formación San José en río Seco, departamento Santa María, provincia de Catamarca. Argentina. Ameghiniana 41, 423-436.

Anzótegui, L.M., Horn, Y., Herbst, R., 2007. Paleoflora (Fabaceae y Anacardiaceae) de la Formación Andalhuala (Plioceno Inferior), provincia de Catamarca, Argentina. Ameghiniana 44, 525-535.

APG IV, 2016. An update of the Angiosperm Phylogeny Group classification for the orders and families of flowering plants. APG III. Bot. J. Linn. Soc. 181, 1-20.

Aragón, E., Romero, E.J., 1984. Geología, Paleoambientes y paleobotánica de yacimientos terciarios del occidente de Río Negro, Neuquén y Chubut. $9^{\circ}$ Congreso Geológico Argentino. Actas 4, 475-507.

Arambarri, A.M., Novoa, M.C., Bayón, N.D., Hernández, M.P., Colares, M.N., Monti, C., 2011. Ecoanatomía foliar de árboles y arbustos de los distritos chaqueños occidental y serrano (Argentina). Bol. Soc. Argent. Bot. 46, 251-270.

Barreda, V.D., Palazzesi, L., 2014. Response of plant diversity to Miocene forcing events: The case of Patagonia. In: Stevens, W.D., Montiel, O.M., Raven, P.H. (Eds.), Paleobotany and Biogeography: A Festschirt for Alan Graham in his 80th. Miss. Bot. Gard, pp. 1-25.

Barreda, V.D., Anzótegui, L.M., Prieto, A., Aceñolaza, P., Bianchi, M.M., Borromei, A.M., Brea, M., Caccavari, M., Cuadrado, G.A., Garralla, S., Grill, S., Guerstein, G.R., Lutz, A.I., Mancini, M.V., Mautino, L.R., Ottone, E.G., Quattrocchio, M.E., Romero, E.J., Zamaloa, M.C., Zucol, A., 2007. Diversificación y cambios de las angiospermas durante el Neógeno en Argentina. Asoc. Paleontológica Argent. Publicación Especial 11, 173-191.

Barreda, V.D., Palazzesi, L., Marenssi, S., 2009. Palynological record of the Paleogene Río Leona Formation (southernmost South America): stratigraphical and paleoenvironmental implications. Rev. Palaeobot. Palynol. 154, 22-33.
Bechis, F., Encinas, A., Concheyro, A., Litvak, V., Aguirre-Urreta, B., Ramos, V., 2014. New age constraints for the Cenozoic marine transgressions of Northwestern Patagonia, Argentina $\left(41^{\circ}-43^{\circ} \mathrm{S}\right)$ : paleogeographic and tectonic implications. J. S. Am. Earth Sci. $52,7 z 93$

Bechis, F., Encinas, A., Valencia, V.A., Ramos, V.A., 2015. Analyzing the transition from extension to contraction at the North Patagonian Andes. $15^{\circ}$ Congreso Geológico Chileno. Actas 737-739.

Berchtold, F., Presl, J.S., 1820. O prirozenosti rostlin. Krala Wiljma Endersa, Prague.

Berry, E.W., 1924. A late Tertiary flora from Bahia, Brazil. Johns Hopkins Univ. Stud. Geol. 5, 1-137.

Berry, E.W., 1925. Miocene flora from Patagonia. Johns Hopkins Univ. Stud. Geol 6, 183-223.

Berry, E.W., 1928. Tertiary fossil plants from the Argentine Republic. Proc. United States Natl. Museum 73, 1-27.

Berry, E.W., 1937. Neogene plants from Río Turbio in the territory of Santa Cruz, Patagonia. John Hopkins Univ. Stud. Geol. 12, 91-97.

Berry, E.W., 1938. Tertiary flora from the Rio Pichileufú, Argentina. Johns Hopkins Univ. Stud. Geol. 12, 11-49.

Berry, E.W., 1939a. The fossil flora of Potosi, Bolivia. Johns Hopkins Univ. Stud. Geol. 13 9-68.

Berry, E.W., 1939b. Fossil plants from the State of Anzoategui, Venezuela. Johns Hopkins Univ. Stud. Geol. 13, 137-161.

Brown, R., 1818. Narrative of an Expedition to Explore the River Zaire, Usually Called the Congo, in South Africa, in 1816. John Murray, London.

Burkart, R., Bárbaro, N.O., Sánchez, R.O., Gómez, D.A., 1999. Ecoregiones de la Argentina. Administración de Parques Nacionales y Secretaría de Recursos Naturales y Desarrollo Sustentable. Buenos Aires.

Burnham, R.J., Carranco, N.L., 2004. Miocene winged fruits of Loxopterygium (Anacardiaceae) from the Ecuadorian Andes. Am. J. Bot. 91, 1767-1773.

Cabello, A., Donoso Zegers, C., 2013. Lithraea caustica (Molina) Hook. et Arn. Litre (Anacardiaceae). In: Donoso Zegers, C. (Ed.), Las Especies arbóreas de los bosques templados de Chile y Argentina, Autoecología (Segunda Edición). Marisa Cúneo Ediciones, Valdivia, Chile, pp. 334-340.

Cabrera, A.L., 1976. Regiones Fitogeográficas Argentinas. Enciclopedia Argentina de Agricultura y Jardinería, Tomo II, Fasciculo 1. Editoral Acme, Buenos Aires.

Césari, S., Panti, C., Pujana, R., Francis, J.E., Marenssi, S., 2015. The late Oligocene flora from the Río Leona Formation, Argentinian Patagonia. Rev. Palaeobot. Palynol. 216, 143-158.

Cornou, M.E., Quattrocchio, M., Martínez, M.M., 2014. Palinoestratigrafía de la Formación Salto del Macho, Paleógeno de la Cuenca de Ñirihuau, Argentina. Ameghiniana 51 556-571.

Das, A., Bucksch, A., Price, C.A., Weitz, J.S., 2014. ClearedLeavesDB: an online database of cleared plant leaf images. Plant Methods 10 (1), 8.

Demaio, P., Ulf, O.K., Medina, M.J., 2015. Árboles nativos de Argentina. Tomo I, Centro y Cuyo. Ecoval Ediciones, Córdoba.

Dusén, P., 1899. Über die tertiäre Flora der Magellanslander. Wissenchtaftliche. Ergebnisse 848 der Schwedischen Expedition nach der Magellanslandern. 1895-1897. Band 1, 84-107.

Ellis, B., Douglas, C.D., Hickey, L.J., Johnson, K.R., Mitchell, J.D., Wilf, P., Wing, S.L., 2009 Manual of Leaf Architecture. The New York Botanical Garden Press and Cornell University Press, New York.

Engelhardt, H., 1891. Ueber Tertiärpflanzen von Chile. Abhandlungen der Senckenbergischen Naturforschenden esellschaft 16, 629-692.

Feruglio, E., 1941. Nota preliminar sobre la Hoja 40B, San Carlos de Bariloche. Boletín de Informaciones Petroleras 18, 27-64.

Fiori, A., 1939. Fillite terziare della Patagonia. II. Fillite del Río Ñirihuau. Giorn. Geol. 13, 1-27.

Forzza, R.C., Filardi, F.L.R., Condak, J.P.S., Accardo, Filho M.A.P., Leitman, P., Monteiro, S.H.N., Monteiro, V.F., 2015. Herbário Virtual Reflora. UNISANTA Bioscience. 4 (6), 88-94 Website. http://reflora.jbrj.gov.br/reflora/herbarioVirtual/accessed on October 9th, 2018

Fu, Q.-Y., Li, L., Jin, J.-H., Liu, X.-Y., Quan, Ch., 2017. Mummified fruits of Choerospondias nanningensis sp. nov. (Anacardiaceae) from the upper Oligocene of a low latitude site in East Asia. J. Syst. Evol. 55, 477-483.

Giacosa, R., Heredia, N., Césari, O., Zubia, M., González, R., Faroux, A., 2001. Descripción geológica de la Hoja 4172-IV, San Carlos de Bariloche, Provincias de Río Negro y Neuquén. vol. 279. Servicio Geológico Minero Argentino, Instituto de Geología y Recursos Minerales, p. 77 (Boletín).

González Bonorino, F., González Bonorino, G., 1978. Geología de la región de San Carlos de Bariloche. Asociación Geológica Argentina, Revista 33, 175-210.

Hickey, L.J., 1973. Classification of the architecture of dicotyledoneous leaves. Am. J. Bot. 60, 7-33.

Hünicken, M., 1967. Flora Terciaria de los estratos de Río Turbio, Santa Cruz (Niveles plantíferos del arroyo Santa Flavia). Revista de la Facultad de Ciencias Exactas Físicas y Naturales de la Universidad de Córdoba. vol. 27 pp. 139-227.

Kvaček, Z., Teodoridis, V., Zajícová, J., 2015. Revision of the early Oligocene flora of Hrazený hill (formerly Pirskenberg) in Knížecí near Šluknov, North Bohemia. Acta Musei Nationalis Pragae, Series B, Historia Naturalis / Sborník Národního muzea řada B, prírodní vědy. 71, 55-102.

Leaf Architecture Working Group, 1999. Manual of Leaf Architecture - Morphological Description and Categorization of Dicotyledonous and Net-Veined Monocotyledonous Angiosperms. Smithsonian Institution, Washington D.C.

Manchester, S.R., Wilde, V., Collinson, M.E., 2007. Fossil cashew nuts from the Eocene of Europe: Biogeographic links between Africa and South America. Int. J. Pl. Sci. 168 1199-1206.

Martinez, L.C.A., Pujana, R.R., 2010. Sobre la presencia de Resinaxylon schinusoides Pujana en la Formación San Julián (Oligoceno), Santa Cruz, Patagonia argentina. Ameghiniana 47, 535-539. 
Martínez-Millán, M., Cevallos-Ferriz, S.R.S., 2005. Arquitectura foliar de Anacardiaceae. Rev. Mex. Biodivers. 76, 137-190.

Mautino, L.R., Anzótegui, L.M., 2014. Novedades palinológicas de las formaciones San José y Chiquimil (Mioceno medio y tardío), noroeste de Argentina. Rev. Mus. Argentino Cienc. Nat., n.s. 16, 143-164.

Mercado, M.I., Slanis, A., Ruiz, A.I., Ponessa, G.I., 2014. Morfoanatomía y arquitectura foliar de Lithraea molleoides (Anacardiaceae). Lilloa 51, 209-217.

Metcalfe, C., Chalk, L., 1950. Anatomy of the Dicotiledons. Vol. I. Clarendon Press, Oxford.

Muñoz, J. de D., 1999. Anacardiaceae. In: Zuloaga, F.O., Morrone, O. (Eds.), Catálogo de Las Plantas Vasculares de la República Argentina. II. Monographs in Systematic Botany from the Miss. Bot. Gard, pp. 41-46.

Muñoz, J. de D., 2000. Anacardiaceae. In: Hunziker, A.T. (Ed.), Flora Fanerogámica Argentina. Programa PROFLORA (CONICET), Buenos Aires, pp. 1-28.

Panti, C., 2018. Fossil leaves of subtropical lineages in the Eocene-?Oligocene of southern Patagonia. Hist. Biol. https://doi.org/10.1080/08912963.2018.1488934.

Paredes, J.M., Giacosa, R.E., Heredia, N., 2009. Sedimentary evolution of Neogene continental deposits (Ñirihuau Formation) along the Ñirihuau River, North Patagonian Andes of Argentina. J. S. Am. Earth Sci. 28, 74-88.

Passalia, M.G., Barreda, V., Bechis, F., Panti, C., Caviglia, N., 2016. New micro- and megafloral records from the upper section of Ñirihuau Formation (Middle Miocene) Río Negro Province, Argentina. $11^{\circ}$ Congreso de la Asociación Paleontológica Argentina. Resúmenes, pp. 76-77.

Pell, S.K., Mitchell, J.D., Miller, A.J., Lobova, T.A., 2011. Anacardiaceae. In: Kubitzki, K. (Ed.), The Families and Genera of Vascular Plants. Flowering Plants. Eudicots: Sapindales, Cucurbitales, Myrtaceae. Springer, Berlin, pp. 7-50.

Poole, I., Hunt, R.J., Cantrill, D.J., 2001. A fossil wood flora from King George Island: ecological implications for an Antarctic Eocene vegetation. Ann. Bot. 88, 33-54.

Pujana, R.R., 2009. Fossil woods from the Oligocene of southwestern Patagonia (Río Leona Formation). Atherospermataceae, Myrtaceae, Leguminosae and Anacardiaceae. Ameghiniana 46, 523-535.

Qiong-Yao, Fu., Li, L., Jin, J.-H., Liu, X.-Y., 2017. Mummified fruits of Choerospondias nanningensis sp. nov. (Anacardiaceae) from the upper Oligocene of a low latitude site in East Asia. J. Syst. Evol. 55, 477-483.
Quattrocchio, ME Martínez M.A Asensio, M. Cornou, M.Ey Olivera, D.E 2012. Palynology of El Foyel Group (Paleogene), Ñirihuau Basin, Argentina. Rev. Bras. Paleontol. 15, 67-84.

Ramírez, J.L., Cevallos-Ferriz, S.R.S., 2002. A diverse assemblage of Anacardiaceae from Oligocene sediments, Tepexi de Rodriguez, Puebla, México. Am. J. Bot. 89, 535-545.

Romero, E.J., 1993. South American Paleofloras. In: Goldblatt, P. (Ed.), Biological Relationships between Africa and South America. Yale University Press, New Haven and London, pp. 62-85.

Romero, E.J., Dibbern, M.C., 1984. Floras fósiles cenozoicas. $9^{\circ}$ Congreso Geológico Argentino. Relatorio. pp. 373-382.

Silva-Luz, C.L., Pirani, J.R., Mitchell, J.D., Daly, D., Capelli, N.V., Demarco, D., Pell, S.K. Plunkett, G.M., 2019. Phylogeny of Schinus L. (Anacardiaceae) with a new infrageneric classification and insights into evolution of spinescence and floral traits. Mol. Phylogenet. Evol. 133, 302-351.

Stevens, P.F., 2001. Angiosperm Phylogeny Website. Version 14, July 2017 [and more or less continuously updated since]. onwards. http://www.mobot.org/MOBOT/research/APweb/.

Troncoso, A., 1992. La Tafoflora terciaria de Quinamávida (VII Región, Chile). Bol. Mus. Nac. Hist. Nat. 43, 155-178.

Vento, B., Prámparo, M.B., 2018. Angiosperm association from the Río Turbio Formation (Eocene-?Oligocene) Santa Cruz, Argentina: revisión of Hünicken's (1955) fossil leaves collection. Alcheringa 42, 125-153.

Weeks, A., Zapata, F., Pell, S.K., Daly, D.C., Mitchell, J., Fine, P.V.A., 2014. To move or evolve: Contrasting patterns of intercontinental connectivity and climatic niche evolution in "Terebinthaceae" (Anacardiaceae and Burseraceae). Front. Genet. 5, 409.

Wheeler, E., Srivastava, R., Manchester, S., Baas, P., 2017. Surprisingly modern latest Cretaceous-earliest Paleocene woods of India. IAWA J. 38, 456-542.

Zuloaga, F.O. Morrone, O., Belgrano, MJ., 2008. Catálogo de las plantas vasculares del Cono Sur (Argentina, Sur de Brasil, Chile, Paraguay y Uruguay). Monographs in Systematic Botany from the Miss. Bot. Gard (107: i-xcvi + 1-3348). 